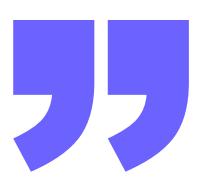

\title{
THE TRANSLATION EVALUATION OF GOOGLE TRANSLATION
}

Putu Ayu Anastasya Putri'1, I Gusti Ngurah Parthama², Putu Lirishati Soetama ${ }^{3}$

English Department, Faculty of Arts, Udayana University ${ }^{123}$

ayuputri7425@gmail.com, ngrpart77@yahoo.com,

lirishati_soethama@unud.ac.id

\begin{abstract}
Machine translation (MT) offers great assistantship when people have difficulties in understanding or comprehend text of their non-native language both in spoken and

Journal History

Submitted 26 th January 2021

Revised 14th March 2021

Accepted 16th April 2021

Published 29th July 2021

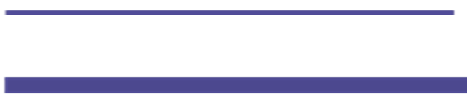

Keywords:

Google Translation, Translation Procedures, Translation Evaluation written language. One kind of machine translation is Google Translation that can be got on their hand just by using mobile phone. This machine can help people to translate the text from one language to another one, in short time. This study aims at finding out the translation procedures found in the translation product by Google Translation and analyzing the errors occurred in Google Translation product. The data of this study are in the form of written data taken from a bilingual children story book of archipelago legend, which consists of 100 lines. There is a source language text in Bahasa Indonesia which is translated into English by using Google translation. The texts are chosen as it contains several sentences that are constructed by paying attention on the rhyme of ending sounds. The data of this study were analyzed through qualitative method. The translation results were analyzed based on translation procedures proposed by Vinay and Dalbernet (1989).Based on the analysis, it can be concluded that translation procedures used by Google Translation found in the data source are borrowing, calque, literal, transposition, modulation, equivalence, and adaptation. The most dominant type of translation procedure is literal translation. It has the highest frequency data; with a total of 50 data (50\%). Some errors are found in the result of Google translation. They are the errors in the use of pronoun, the use of plural and singular noun and inconsistency in the translation of name. Those errors are caused by limitation of machine in detecting the context of the text. Thus, the translated text is incoherent.
\end{abstract}




\section{INTRODUCTION}

Nowadays, people are really eager to learn foreign languages. They learn these languages to communicate to other people from other continents. For that reason, English as one of the most spoken languages is studied by non-native speaker to create a networking study about knowledge of the language, to understand what is learned, and etc. In learning the language, those non-native speakers may choose several different ways. They meet English native speaker, read many English books, or even translating their native language into English for a better comprehension. A survey reported by Coffey in 2012 indicates that many people choose the translation method since many kinds of supporting software's, machine translation, are available for free.

Machine translation (MT) offers a great assistantship when they have difficulties in understanding or comprehend their non-native language both in spoken and written language. Coffey (2012) reported a survey that around $18 \%$ of people use the MT regularly and another $18 \%$ use it once or twice. In addition, the expansion of the technology makes the users are able to get the machine translation on their hand. Similarly, with the widespread and growing use of mobile phones, there are an increasing number of manufactures providing translation software for these devices (Hutchin, 2009).

The vary of machine translation may result in the different translation product. Those differences might be caused by the difference's translation procedure applied during the translation process by each software. Vinay and Dalbernet (1973) stated that translation procedures are used for sentences and the smaller unit of language. Those translation procedures are as follows: (1) Borrowing, (2) Calque, (3) Literal Translation, (4) Transposition, (5) Modulation, (6) Equivalence, and (7) Adaptation. These procedures might determine the different quality of the translation product made by various MT software.

Research about evaluating quality of the translation product of machine translation seems to be an under-researched area within recent period. Hampshire and Salvia (2010) said that there is only small number of studies which rank the MT in academic work. Moreover, the ranking system seems to offer unsatisfactory result. This inadequate result was yielded from its limited type of analyzed machine translation, unclear final result about the most appropriate machine translation and the vague criteria evaluation of analyzing the machine translation. For example, Savoy and Dolamic (2009) analyzed and rank only based on three machines translation which translate French and English document. They found that Google Translate as one of the tools, still got several problems on its lexical, idiom and sensitivity. However, the quality of the translation product can 
be examined through several criteria. According to Barnwell (1980), there are three criteria which have to be fulfilled in order to make a good translation. They are (1) Accuracy, (2) Clarity, and (3) Naturalness. However, when it seems impossible to reconcile all three, the 'accuracy' must have priority. Therefore, this article discussed about the evaluation of translation product by Google Translation.

\section{METHODS}

This article was focused on classifying the translation procedures and the dominant type of translation procedures found in the translation product of Google translation. The source text is in Bahasa Indonesia as a source language text. Each sentence in the text is translated from Bahasa Indonesia into English using Google translation as the main Machine Translation. Besides, this study also discusses the errors occurred in the translation product in terms of lexical choice, syntax and semantics.

In collecting the data, there were some steps that needed to be done. First, the data were collected by choosing the type in the source language, Bahasa Indonesia. Second, the data found were read and classified to the purpose of the study. Third, the data were grouped per line and then translated into English using Google Translation machine. The collected data then grouped and classified per line number which became the prominent data to be analyzed in this article.

The data were analyzed through qualitative and quantitative methods. The data in this article were analyzed by the following steps. Firstly, the analysis was focused on the Indonesian - English translation quality produced by Google Translation. After the types of translation procedures found in those data, these translation procedures then grouped based on translation procedures as stated by Vinay and Dalbernet (1989) such as borrowing, calque, literal translation, transposition, modulation, equivalence, and the last is adaptation. Secondly, these group of translation procedures then counted and quantitatively convert into percentage calculation. As a result, the dominant type among this procedure would be found. Finally, in addition to find the type of translation procedure, the analysis on finding the error conducted in terms of grammatical context. Thus, the final findings depicted the quality of the Google Translation product. Lastly, the results were presented in the form of table.

\section{THEORETICAL BASIS}

Fahim (2018) conducted a research entitled "Tingkat Keakuratan Google Translate Berdasarkan Jenis Teks". This study gives contribution to this article in terms of the information about some errors found in the Google translation result. 
Melita (2016) published a research about Google translation's product entitled "An Analysis of Accuracy Level of Google Translate in English-Bahasa Indonesia and Bahasa Indonesia-English Translations". This study provides a lot of information about the Google translate result for this article.

Hampshire and Salvia (2010) in their study entitled "Translation and the Internet: Evaluating the Quality of Free Online Machine Translators", reviewed the need of ranking system and the ranking result of several free online machine translators.

\section{The Process of Translation}

Larson (1984:4) stated that, in translating a text, the translator's goal is an idiomatic translation which makes every effort to communicate their meaning of the SL text into the natural forms of the receptor language. The discovered meaning is then re-expressed or reconstructed using the lexicon and grammatical structure which are appropriate in the receptor language and its cultural context. The diagram of the translation process as stated by Larson, can be seen as follows;

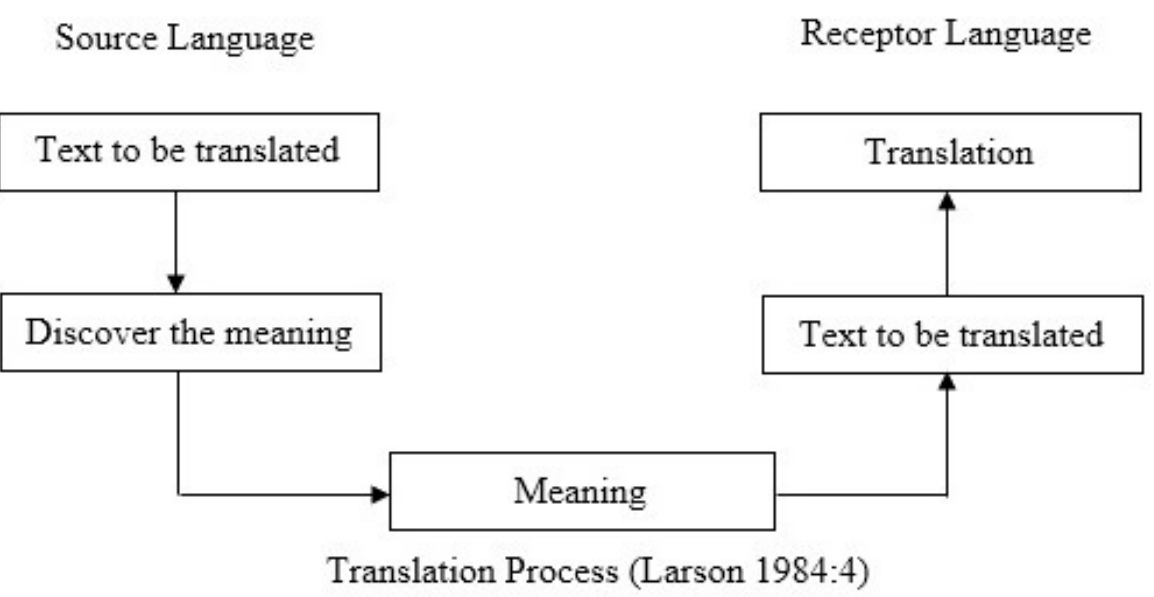

\section{Google Translation}

In general, machine translation (MT) is a kind of tool or software which is used to translate a source language (SL) into a certain target language (TL). There are several MTs which is used by the users nowadays. One of them is Google Translation. According to Kartika (2017), Google Translation is a free multilingual machine translation service developed by Google, to translate text, speech, images, sites, or real-time video from one language into another. Even, its auto detection can be figured out which language that users understand. Users can translate entire web pages or documents easily as well. That is why, Google Translation is one of the most popular MT. Google translate enables users to translate different written texts from one language to another and it provides translation of 90 languages. 


\section{Translation Procedures}

The processes of translation are supported by Vinay and Dalbernet (1973) which proposed seven procedures of translation. They stated that translation procedures are methods applied by translators when they formulate an equivalence for the purpose of transferring elements of meaning from the source language (SL) to the target language (TL). More than one procedure can be seen in one translation, and some translations may result from a cluster of procedures that is difficult to discern. The seven procedures in the process of translation are:

\section{a. Borrowing}

Borrowing is the simplest of all translation methods. It refers to a case where a word or an expression is taken from the SL and used in the TL, but in a 'naturalized' form is made to conform to the rules of grammar or pronunciation of the TL. It is usually used in terms of new technical or unknown concepts.

Haugen (2009:27 cited in Sari 2009) argued that there are some possibilities that may occur in this procedure:

a) Borrowing with no change in form and meaning (pure loanwords). For examples: email $\rightarrow>$ email, internet $\rightarrow$ internet.

b) Borrowing with changes in form but without changes the meaning (mixed loanword). For examples: account $->$ akun, compensation $>$ kompensasi.

c) Borrowing when part of the terms is native and another is borrowed, but the meaning is fully borrowed (loan blends). For examples: internet provider $-\rightarrow$ penyedia layanan internet.

b. Calque

Calque, refers to the case where the translator imitates the structure or manner of expression of the SL in his translation. Calque may introduce a structure that is stranger from the TL. For instance, "photo studio" in English is still translated as photo studio in Bahasa Indonesia, although there is normally no such Modifier + Head construction in Bahasa Indonesia's Noun Phrase.

c. Literal Translation

Literal translation is a direct transfer of a SL text into a grammatically and idiomatically appropriate to TL text. Principally, literal translation is a unique solution in which is reversible and complete in itself. For examples, "black market" in English is translated to be pasar gelap in Bahasa Indonesia.

d. Transposition

Transposition involves in replacing word class with another category without changing the meaning of the message. The method also involves a change in the grammatical change that occurs in translation from SL to TL (singular to plural, position of adjective, changing the word class or 
part of speech). For instance, a compound "keyword" in English is translated as Kata Kunci (Phrase) in Bahasa Indonesia.

e. Modulation

Modulation is a change in a point of view that allows us to express the same phenomenon in a different way. Modulation as a procedure of translation occurs when there is a change of perspective accompanied with a lexical change in the TL. There are two types of modulation, i.e. Free or Optional Modulation and Fixed or Obligatory Modulation. For instance, "He was killed in the war" in English is translated as Dia gugur dalam perang in Bahasa Indonesia. 'Negated contrary', which is a procedure that relies on changing the value of the ST in translation from negative to positive or vice versa, is also considered as fixed modulation. For example, "It isn't expensive" is translated to be It's cheap.

f. Equivalence

This term is used to refer to the cases where languages describe the same situation by different stylistic or structural means. For example, an interjection "Ouch!" in English can be translated to be Aduh or Aw in Bahasa Indonesia. An English idiom "Don't cry over spoiled milk" may can be translated as Nasi sudah menjadi bubur in Bahasa Indonesia.

g. Adaptation

Adaptation is used in those cases where the type of situation being referred to by the SL message is unknown in the TL culture. In such case, the translators have to create a new situation that can be considered as being equivalent. For instance, "Take a bath" in English is translated into Mandi in Bahasa Indonesia.

\section{Translation Errors}

Machine translation is a kind of translation that involved the ability of machine to transfer the meaning of source language text to the target language text. Google Translate as a kind of machine translation is a website sfotware in which you type something in English then the site shows you the word in another language. Languages never match each other word for word. Since it is a translation result of machine, so it can result in some errors in the translation product. According to Nord (1997:75) translation errors can be classified into four categories namely Pragmatic, Cultural, Linguistic and Text Specific Translation error. The Pragmatic translation errors caused by inadequate solutions to pragmatic translation problems such as a lack of receiver orientations. Meanwhile, Cultural translation errors, due to an inadequate decision with regard to reproduction or adaptation of culture specific conventions. Then, Linguistics translations errors, caused by an inadequate translation when the focus is on language structures. Finally, the text-specific translation errors, which are related to a text-specific translation problem and, like the corresponding translation 
problems, can usually be evaluated from a functional or pragmatic point of view.

\section{RESULTS AND DISCUSSION}

\section{The Analysis of Translation Process}

The translation product of Google translation machine is analyzed based on the theory of translation procedures. By looking at the translation result, the procedures that are used in the process of translation can be defined. Based on the data, this chapter presents and analyzes the data to investigate the procedures and the dominant type of translation procedures.

\section{a. Borrowing}

\section{Data}

\begin{tabular}{|c|c|}
\hline SL & TL \\
\hline 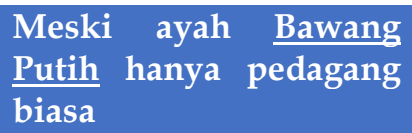 & $\begin{array}{l}\text { Even though Bawang } \\
\text { Putih's father is just an } \\
\text { ordinary trader }\end{array}$ \\
\hline
\end{tabular}

In the data above, borrowing procedure is used in the translation of name. The underlined word Bawang Putih (name) in SL is translated in the same form into Bawang Putih in TL.

\section{b. Calque}

\section{Data}

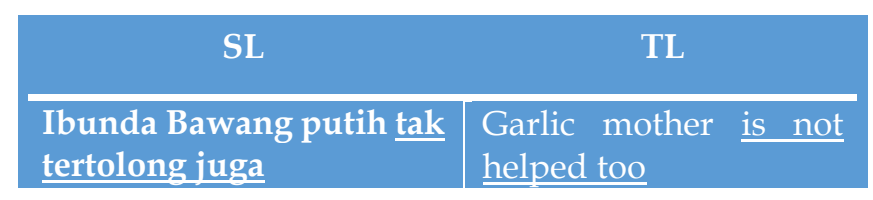

The procedure of calque is used in the translation of verb phrase "tak tertolong" which contains the meaning "there is no way to help and we must accept it'. The verb phrase is translated into "is not helped" in the form of verb phrase too. But in the translation result, the translation of verb phrase remains to translate in the passive form without transferring the meaning of SL. The Google machine translates the form of verb phrase to be the same construction in TL without any concern on the meaning and the construction in TL to transfer the meaning without changing the passive form of SL. 


\section{c. Literal Translation}

\section{Data}

\begin{tabular}{l|l} 
SL & TL \\
\hline $\begin{array}{l}\text { Sang janda terlihat } \\
\text { sangat baik dan ramah }\end{array}$ & $\begin{array}{l}\text { The widow looks } \\
\text { very nice and } \\
\text { friendly }\end{array}$ \\
\hline
\end{tabular}

The data above, Google machine translates the sentence of SL to same form and structure in TL. The structure of SL is noun phrase (sang janda) + verb (terlihat) + adjective phrase (sangat baik) + conjunction (and) + adjective (ramah). It is translated into TL by the construction of noun phrase (the widow) + verb (looks) + adjective phrase (very nice) + conjunction (and) + adjective (friendly). If it is separated word-for-word, it will be (sang janda $=$ the widow, terlihat=looks, sangat baik=very nice, dan=and, ramah=friendly). The translation of the sentence shows that most words in the sentence are translated word for word. Therefore, it can be concluded that the sentence is translated in literal procedure.

\section{d. Transposition}

\section{Data}

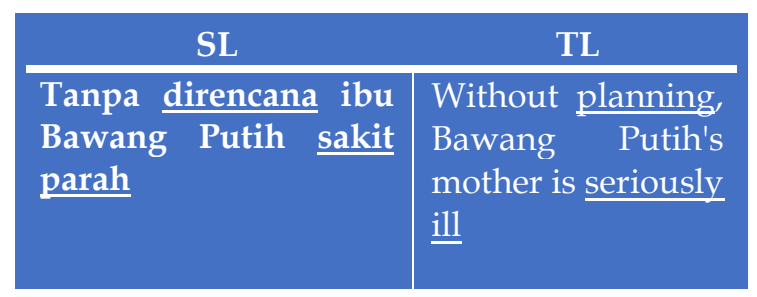

The data above, Google machine translates the word direncana to be 'planning'. In this translation, there is shift of word class from a verb direncana in SL to be a noun 'planning' in TL. The shift occurred in this translation is a change of word class from a verb into a noun.

e. Modulation

\section{Data}

\begin{tabular}{lr|l}
\multicolumn{2}{c}{ SL } & \multicolumn{2}{c}{ TL } \\
\hline $\begin{array}{l}\text { Bawang } \\
\text { berjalan seorang diri }\end{array}$ & Garlic goes alone \\
\hline
\end{tabular}

Modulation procedure is used in this translation to transfer the same message or meaning of SL into TL by changing the point of view. It can be seen in the translation of verb berjalan in SL into 'goes' in TL. Those words have same message that is to show a movement of the subject from one place to another. The change in the point of view can be seen from the SL focus on the way of subject movement, while in TL, the focus changes into the movement only without any adverb to show the way of movement. The 
change on the focus of verb has the same message that is to show the action of the subject to do a movement even though by eliminating the way of movement in TL.

\section{f. Equivalence}

\section{Data}

\begin{tabular}{|c|c|}
\hline SL & TL \\
\hline $\begin{array}{l}\text { Melihat Bawang } \\
\text { Putih yang selalu } \\
\text { bermuram durja }\end{array}$ & $\begin{array}{l}\text { Seeing Garlic that is } \\
\text { always moping }\end{array}$ \\
\hline
\end{tabular}

From data above, the idiomatic phrase bermuram durja in SL is translated into a word 'moping' in TL. The machine uses common word which is recognized in daily conversation bermuram durja into 'moping'. In source language, the phrase bermuram durja contains the meaning of feeling sorry and the word 'moping' in target language contains the meaning "spending time by doing nothing and feeling sorry for yourself". Those expressions have the same reference of sad feeling.

\section{g. Adaptation}

\section{Data}

\begin{tabular}{l|l} 
SL & TL \\
\hline $\begin{array}{l}\text { Walau tabib berusaha } \\
\text { tanpa menyerah }\end{array}$ & $\begin{array}{l}\text { Even though the } \\
\text { physician } \\
\text { without giving up }\end{array}$ \\
\hline
\end{tabular}

The Google machine uses adaptation procedure in finding the equivalent of word tabib in TL. In SL, the word tabib is a term to refer the person who heals the sick people traditionally. While, in TL the equivalent of the word is 'physician' which refers to a doctor, especially one who is a specialist in general medicine and not surgery. In Indonesia, tabib does not use a modern way in healing the patient, and in English the physician is not doing surgery (a modern healing technique). It means that those both words have the equivalence in meaning and according to each situation in SL and TL culture.

\section{The Dominant Type of Translation}

Based on the following 7 translation procedures, the most dominant type of translation procedure is literal translation. It has the highest frequency data; they are 50 data (50\%). This procedure is dominantly used by Google machine to transfer the message or meaning from SL into TL since the machine can only detect the sentence word by word. This term is also used to refer to cases where languages describe the same situation by different stylistic or structural. Moreover, some errors are found in the result of Google translation. They are in the use of pronoun, noun and 
inconsistency in the translation of name. Those errors are caused by limitation of machine in detecting context of the text. Therefore, it cannot maintain the coherency of the target text and can cause confusing towards the target readers imagination.

\section{Translation Errors}

The identified data are in the form of phrases and sentences. In the results of translation, there are several variations of translation errors found; (1) Translation Errors in The Use of Pronoun, (2) Translation Errors in The Use of Plural and Singular Nouns, (3) Translation Errors in The Inconsistency Use of Subject's Name.

\section{CONCLUSION}

Based on the foregoing discussion, there are seven types of translation procedure found in the data namely Borrowing, Calque, Literal Translation, Transposition, Modulation, Equivalence, and Adaptation. In addition, among those seven different types of translation procedure found, the Literal Translation Procedure was found as the most dominant type performed by the Google Translation. It covers almost half from all the analyzed data. Finally, there are four types of errors found during the translation process performed by Google Translations. Those errors are the errors in the use of pronoun, the use of plural and singular noun and inconsistency in the translation of name.

\section{REFERENCES}

Arnold, E. A. 1994. Machine Translation: An Introductory Guide. London: Blackwells-NCC.

Barnwell, Katharine. 1980. Introduction to semantics and translation. Second edition. Dallas: Summer Institute of Lingustics.

Bell, R. T. 1991. Translation and Translating: Theory and Practice. London: Longman.

Brislin, R. W. (1976). Translation: Application and Research. New York: Gardner Press Inc.

Catford, J. C. 1974. A Linguistic Theory of Translation. Oxford: Oxford University Press.

Coffey, Neil. 2012. How Often Do People Use Machine Translation? http://french -linguistics-dev.blogspot.co.id/2012/06/how-oftendo-people-use-machine.html.

(Accessed on April, 20th, 2016 at 06.46 P.M.) 
Chunyu, K. and Wong. 2008. Comparative Evaluation of Online Machine Translation System with Legal Texts. City University of Hong.

http://www.allnet.org/mm/Publications/llj/LLJ-Archieves/Vol100/pub_1lj_v100n02/2008-16.pdf.

(Accessed on April 28th, 2016 at 10.32 A.M.)

Fahim, Mohammad. 2018. “Tingkat Keakuratan Google Translate Berdasarkan Jenis Teks: Kajian Terjemahan" (S1 Thesis). Bandung: Program Studi Bahasa Inggris, Fakultas Bahasa, Universitas Widyatama.

Halliday, M. 1994. Introduction to Functional Grammar. New York: Routledge.

Hampshire, S; Salvia C. 2010. Translation and the Internet: Evaluating the Quality of Free Online Machine Translators. Universitat de Barcelona.

https://ddd.uab.cat/pub/quadrens/11385790n17/11385790n17p197.pdf.

(Accessed on May 1st, 2016 at 07.41 P.M.)

Hilma, Rila. 2011. "Literal Translation Using Google Translate in Translating the Text from French to English in Digital Tourism Brochure Bienvenue À Paris". Jakarta: Program Studi Hotel Management, Fakultas Ekonomi dan Bisnis, Universitas Bina Nusantara.

https://www.neliti.com/id/publications/167785/literal-translationusing-google-translate-in-translating-the-text-from-french-t

(Accessed on January 21st, 2021 at 20.54 P.M)

Hutchins, E. 1988. Cognition in the Wild. Canada: MIT Press.

Hutchins, W. J. and Somers, H. L. 1992. An Introduction to Machine Translation. London: Academic Press.

https: / / www.google.com/url?sa=t\&rct=j\&q=\&esrc=s\&source=web\&cd= \&cad $=$ rja\&uact $=8 \& v e d=2$ ahUKEwiNitSs34PuAhUEfH0KHaewAsE QFjAAegQIAhAC\&url=http\%3A\%2F\%2Fwww.hutchinsweb.me.uk \%2FIntroMT-

TOC.htm\&usg=AOvVaw32HjWHMUDHpotlljFOy9zB

(Accessed on January 3rd, 2021 at 10.28 A.M)

Kartika, Dewi. 2017. “Analysis of Google Translate's Quality in Employing Translation Techniques" (S1 Thesis). Semarang: English Department, Faculty of Languages and Arts, Semarang State University. 
Kucis, et al. 2009. Evaluation of Electronic Translation Tools through Quality Parameters. University of Maribor.

http:/ / www.evrotem.gov.si/Kucis_Seljan_Klasnic\%20Evaluation\%20of\% 20Electronic\%20Translation\%20Tools.pdf.

(Accessed on May 1'st, 2016 at 07.38 P.M.

Larson, M. L. 1984. A Guide to Cross language Equivalence. Maryland: University Press of America.

Lin, G. H and Chien, P. S. C. 2009. Machine Translation for Academic Purposes. University of Southern California.

https:/ / www.google.com/url?sa=t\&rct=j\&q=\&esrc=s\&source=web\&cd= \&cad=rja\&uact $=8 \&$ ved $=2$ ahUKEwj_psDf3YPuAhXNZCsKHahbCP AQFjADegQIDBAC\&url=https\%3A\%2F\%2Ffiles.eric.ed.gov\%2Fful 1text\%2FED513879.pdf\&usg=AOvVaw0sAuyXV-8R1PKv0JAZD5Qa

(Accessed on January 1st, 2020 at 10.24 A.M)

Newmark, P. (1988). A Textbook of Translation. Hertfordshire: Prentice Hall Elt Europe.

Nida, E. A., \& Taber, C. R. (1974). The Theory and Practice of Translation. Leiden: E. J. Brill.

Nord, C. 1997. Text Analysis in Translation: Theory, Methodology and Didactic Application of a Model for Translation-Oriented Text Analysis. Amsterdam: Rodopi.

Nadhianti, Melita. 2016. "An Analysis of Accuracy Level of Google Translate in English-Bahasa Indonesia and Bahasa Indonesia-English Translations" (S1 Thesis). Yogyakarta: English Language and Literature English Education Department, Faculty of Languages and Arts, Yogyakarta State University.

Peng, Li. 2013. “A Survey of Machine Translation Methods”. China: Foreign Language School East China Jiaotong University.

https://www.researchgate.net/publication/275415014_A_Survey_of_Ma chine_Translation_Methods

(Accessed on January 19th, 2021 at 21.14 P.M)

Sanal, Fahrettin. 2008. "Error-Analysis based Second Language Teaching Strategies".

Turkey: Selcuk Universitesi Sosyal Bilimler Enstitusu Dergisi.

http://www.sosyalbil.selcuk.edu.tr/sos_mak/articles/2008/20/FSANAL $\underline{\text { PDF }}$ 
(Accessed on November 23rd, 2019 at 13.15 P.M)

Sari, F. Keumala. 2009. An Analysis of Translation Precedures of Translating Computer Terms in Andrews S. Tanenbaum $3^{\text {rd }}$ Computer Nertworks Into Bahasa Indonesia. Medan: University of Sumatera Utara.

http:/ / repository.usu.ac.id/bitstream/123456789/26358/4/Chapter\%20I. pdf.

(Accessed on May 25th, 2016 at 20.57 P.M.)

Savoy, J; Dolamic, L. 2009. How effective is Google's Translation Service in Search?. Communications of the ACM. No. 10. Vol. 52.

Vinay, J.P. and J. Darbelnet. 1989. Translation Procedures. Readings in Translation Theory. Ed. A. Chesterman. Loimaa: Finn Lectura, 61-69.

Vinay, J.P; Dalbernet, Jean. 1973. The Translaton Studies Reader. Edited by Lawrence Venutiin 2004. London and New York: Routledge. 